\section{The spatial analysis of extrapulmonary tuberculosis spreading and its interactions with pulmonary tuberculosis in Samarinda, East Kalimantan, Indonesia}

\author{
Nataniel Tandirogang, ${ }^{1}$ \\ Wirdah Ulfahaini Mappalotteng, ${ }^{1}$ \\ Eko Nugroho Raharjo, ${ }^{2}$ \\ Swandari Paramitai, ${ }^{3}$ Dewi Embong \\ Bulan, ${ }^{4}$ Yadi Yasir ${ }^{1}$ \\ ${ }^{1}$ Microbiology Laboratory of Medical \\ Faculty Universitas Mulawarman; \\ ${ }^{2}$ Anatomy Pathology Laboratory of \\ Abdul Wahab Sjahranie Hospital; \\ ${ }^{3}$ Public Health Laboratory of Medical \\ Faculty Universitas Mulawarman; \\ ${ }^{4}$ Department of Aquatic Resources \\ Management of Fisheries and Marine \\ Science Faculty Universitas \\ Mulawarman, Samarinda, East \\ Kalimantan, Indonesia
}

\section{Abstract \\ Background: $\quad$ Extrapulmonary} Tubercolosis (EPTB) is an infectious disease that affects tissue outside the lungs. EPTB patients cannot be source of infection, therefore the findings in the community indicate that there are still active pulmonary TB patients acting as a source of infection. Understanding distributions of EPTB can be used as indicator to individuate the unmonitored source of TB transmission in the community.

Objectives: The aim of this study is to analyze EPTB using spatial modeling based on patients' location.

Methods: This study is an observational research with spatial analysis approach using SatScanv.9.4.4 and ArcGis v.10.4. Involving 46 samples of EPTB patients in Anatomy Pathology Laboratory of RSUD Abdul Wahab Sjahranie in 2017 and 7 pulmonary TB patients who were contacts of EPTB patients. The distribution of EPTB patients is mostly located in areas with high population density.

Results: The results showed that the distribution pattern of EPTB patients was mostly in areas with high population densities. Space-time permutation model shows there are 3 clusters of EPTB with a 2.91, $0.97,1.13 \mathrm{~km}$ radius centered on -0.504177 S/117.092132 E, -0.476895 S /117.141700 E, $-0.517031 \mathrm{~S} / 117.092132 \mathrm{E}$.

Conclusion: The distribution of patients with EPTB and pulmonary TB indicates there is an interaction between EPTB and pulmonary TB in the cluster area. Bernoulli model shows that there is 1 cluster of EPTB and pulmonary TB with relative risk 5.29, radius of $3.19 \mathrm{~km}$, and centered on $0.458159 \mathrm{~S} / 117.149945 \mathrm{E}$.

\section{Introduction}

Tuberculosis (TB) is an infectious disease caused by Mycobaterium tuberculosis (M.TB), that can infect lung (pulmonary TB) and other organs outside the lungs (extrapulmonary tuberculosis, EPTB). TB remains a global health problem, with an estimated 6.3 million new TB cases in $2017,16 \%$ of which are EPTB cases. ${ }^{1}$

In recent decades, EPTB cases in developed countries have increased in proportion to the total TB cases. ${ }^{2,3}$ Several studies have been carried out in various countries, and found the highest percentage of EPTB in Brazil (45.6\%), England and Wales (41\%), Iran $(27.3 \%)$, North India $(27.3 \%)$, Korea (20.4\%), and United States (18,7\%), respectively. ${ }^{2-7}$ Meanwhile in Indonesia, the number of national EPTB cases is unclear, even though it can be estimated that there are many EPTB cases in the community following the increase in $\mathrm{TB}$ in the past 5 years, which is went 324,539 cases in 2014 to 511,873 in $2018 .^{8,9}$

Human can become infected with TB when inhaling M.TB from the droplet nuclei. When this tubercle bacillus reaches the alveoli it will be digested by alveolar macrophages, so that most of them will be destroyed or inhibited and only a few of them multiply intracellularly and are released when the macrophages die. The bacillus spreads through blood vessels or lymph vessels to organs outside the lungs, such as lymph nodes, genitourinary, pleura, bones and joints, peritoneal organs, meninges and the central nervous system, which are the most common EPTB manifested organs. ${ }^{10}$ However, EPTB can also occur through reactivation of dormant bacilli or directly from adjacent organs that have been previously infected. ${ }^{11}$ Therefore EPTB is less transmissible ${ }^{7,12,13}$ than pulmonary $\mathrm{TB}$, which makes the presence of EPTB patients in the community makes it possible to be an indicator of active TB as a source of transmission.

Spatial analysis is one way to map the pattern of disease spread so to obtain EPTB surveillance. Spatial analysis is widely used in the health sector to help identify the distribution and clustering of disease cases, individuate high-risk areas, and identify the risk factors that influence them, so to
Correspondence: Nataniel Tandirogang, Microbiology Laboratory, Faculty of Medicine, Universitas Mulawarman, Samarinda, East Kalimantan, Jl. Kerayan Kampus Gn. Kelua, Samarinda 75119, Indonesia.

Tel: +6281346452727

E-mail: nataniel@idikaltim.org

Key words: Extrapulmonary tuberculosis, pulmonary tuberculosis, spatial analysis.

Contributions: NT, WUM, EN, data collecting and analyzing; PS, DEB, manuscript writing; YY, manuscript reviewing and references search.

Conflict of interest: The authors declare no potential conflict of interest.

Funding: The work was supported by a research grant from Medical Faculty, Mulawarman University FY 2018.

Acknowledgements: The authors acknowledged all respondents who were willing to be the sample of this study. All authors are all researchers involved in this study and do not have a conflict of interest.

Clinical trials: This work was registered in ethical clearance committee of A. Wahab Sjahranie hospital, Samarinda, East Kalimantan.

Conference presentation: This paper was presented at an international conference on Infectious Diseases, Biothreats, and Military Medicine (INSBIOMM), 2019 Aug 27-28, Surabaya, Indonesia

Received for publication: 17 February 2020 Accepted for publication: 1 July 2020.

This work is licensed under a Creative Commons Attribution-NonCommercial 4.0 International License (CC BY-NC 4.0).

COPyright: the Author(s), 2020

Licensee PAGEPress, Italy

Infectious Disease Reports 2020; 12(s1):8727 doi:10.4081/idr.2020.8727

increase the efforts to control diseases. ${ }^{14}$ In addition, it also helps in supporting decision making with short time and relatively little cost in terms of health resource management, epidemiological monitoring and disease control. ${ }^{15}$

The aims of this study were to spatially analyze the spread of EPTB based on the location of the patient's residence and to determine the geographical relationship between EPTB sufferers and pulmonary TB patients. 


\section{Materials and Methods}

This study is a cross sectional study with a spatial analysis approach aimed to describe the geographical distribution of EPTB sufferers in the population. The sample in this study were all patients with EPTB who were diagnosed based on the results of histopathological examination and/or FNAB. The diagnosis of EPTB was carried out by pathologist based on the examination of the lymph nodes, breast, intestinal, genitourinary, bone and joint and pleura obtained from the patients of the Abdul Wahab Sjahranie Hospital, Samarinda, from January 2017-December 2018.

All patients were visited at their respective homes, based on the address indicated on the medical record. The coordinates of the patient's residence were carried out using the GPS, and direct interviews were conducted to find out the history of contacts with patients with pulmonary TB in the patient's residence area. All sufferers were in the city of Samarinda spread over $10 \mathrm{sub-}$ districts. Data processing was performed using the GPS Map Coordinate application version 4.5.0, ArcGIS software version 10.4 and SaTScan software version 9.4.4.

\section{Results and Discussion}

There were 69 EPTB patients based on the results of the Anatomic Pathology examination at the Anatomy Pathology Laboratory of the Abdul Wahab Sjahranie Hospital Samarinda. Only 46 people met the criteria and became the study sample. When conducting a field visit, based on the results of interviews, we found 7 pulmonary

Table 1.General description of EPTB patient in Samarinda City.

\begin{tabular}{lc} 
Variable & Total (\%) \\
Age (year) & \\
$0-4$ & $2(4,36)$ \\
$5-14$ & $6(13,04)$ \\
$15-64$ & $38(82,6)$ \\
Sex & \\
Female & $30(65,21)$ \\
Male & $16(34,79)$ \\
\hline Organs Location & \\
KGB & $30(65,22)$ \\
Mamae & $6(13,05)$ \\
Intestinal & $4(8,69)$ \\
Genitourinari & $3(6,52)$ \\
Bones and joints & $2(4,35)$ \\
Pleura & $1(2,17)$ \\
\hline
\end{tabular}

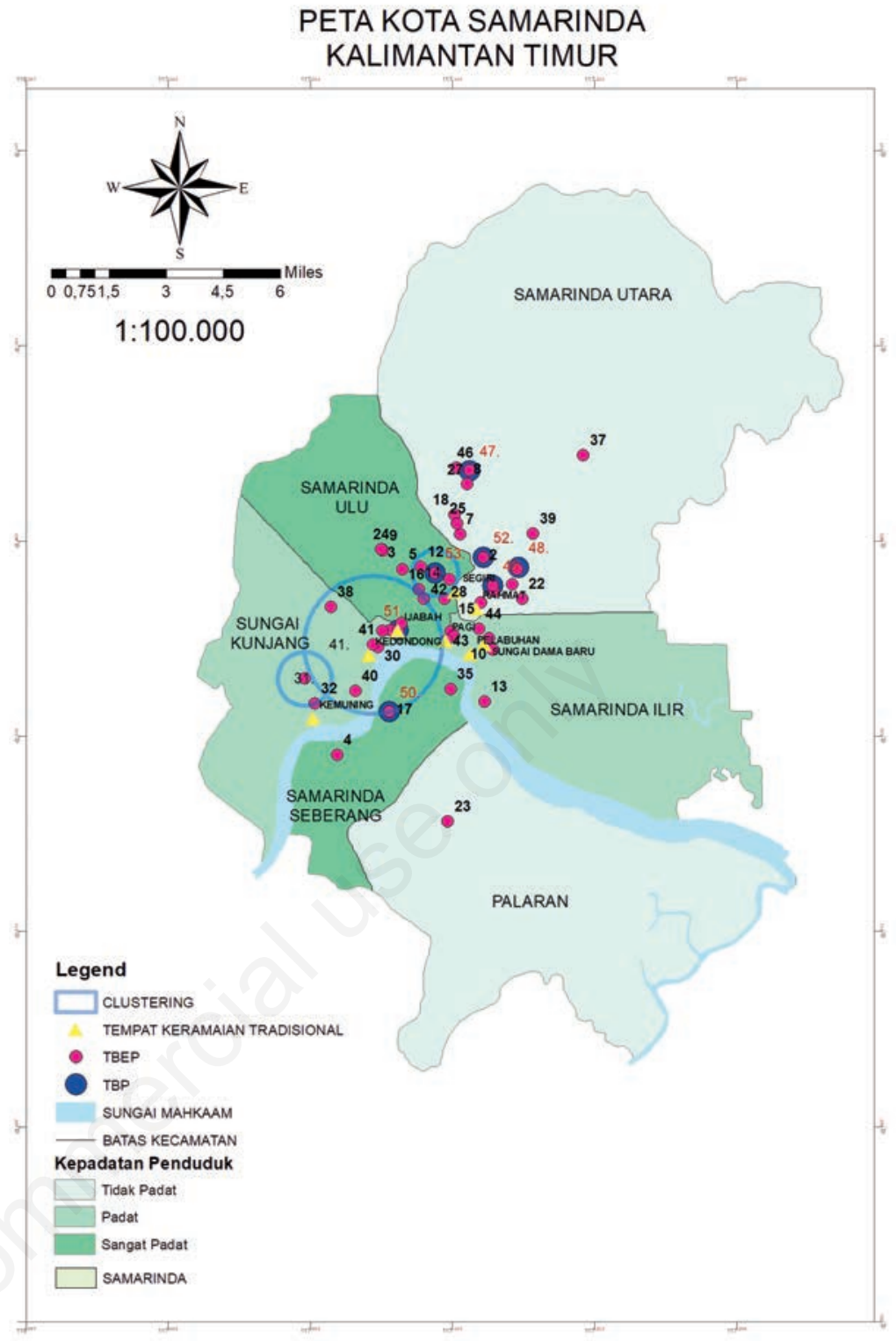

Figure 1. Spatial and pattern distribution of EPTB in Samarinda City. SaTScan SpaceTime Permutation model analysis showed 3 clustering of TBEP. Cluster 1 consisted of 9 patients centered at $-0.504177 \mathrm{~S} / 117.118058 \mathrm{E}$ with a radius of $2.91 \mathrm{~km}$. Cluster 2 consisted of 4 patients centered at $-0.476895 \mathrm{~S} / 117.141700 \mathrm{E}$ with a radius of $0.97 \mathrm{~km}$. Whilst cluster 3 consisted of 2 patients centered at -0.517031 S / 117.092132 E with a radius of $1.13 \mathrm{~km}$

Table 2. Geographical distribution and distribution pattern of EPTP in Samarinda city.

\begin{tabular}{lccc} 
Sub-district & Total EPTB & Percentage (\%) & Population density (people / $\left.\mathbf{k m}^{2}\right)$ \\
Samarinda Ulu & 12 & 26,09 & 6.982 \\
Sungai Kunjang & 9 & 19,57 & 3.500 \\
\hline Samarinda Utara & 8 & 17,39 & 503 \\
Sungai Pinang & 6 & 13,04 & 4.200 \\
\hline Samarinda Kota & 4 & 8,7 & 5.800 \\
Samarinda Ilir & 3 & 6,52 & 3.200 \\
\hline Samarinda Seberang & 2 & 4,35 & 6.200 \\
Palaran & 1 & 2,17 & 200 \\
\hline Loa Janan Ilir & 1 & 2,17 & 2.900 \\
Total & 46 & 100 &
\end{tabular}


TB patients confirmed by the DOTS (Direct observed Treatment, Short-course) program. These patients were approved by the Samarinda City Health Office. Of the 46 EPTB sufferers, $11 \%$ have a history of pulmonary TB, and only $4.3 \%$ have a history of clear contact with pulmonary TB sufferers.

\section{General description}

EPTB data on age, sex, and location of organs offered can be seen in (Table 1). EPTB was found in all age groups, with the highest number recorded in the productive age groups (15-64 years), with $82.6 \%$ of the cases. There are more women than men. For what concerns the location of organs, the most common type of EPTB interested the lymph $(65.21 \%)$.

The results of this study indicate that EPTB occurs mostly in the productive age, among those who are in a place to work or produce something for themselves or others. Therefore, in this age group many work and relate to the outside environment. TB can be transmitted without realizing it through the air that contains TB. ${ }^{16}$ Transmission of TB germs can also occur among toddlers and children. The immune system takes part in this case, as in toddlers and children the immune system has not formed properly, and at a young age the required is low. ${ }^{17}$ This will be increased when attacked by TB infection. The results of this study refer to the types obtained from EPTB sufferers more in women than in men. These results are the same as those from the study conducted by Garcia et al., arguing that women are more at risk from EPTB than men. ${ }^{18}$ These results are also the same in previous studies at Abdul Wahab Sajhranie Hospital in Samarinda in 2016 obtained from 91 EPTB patients, $51.6 \%$ of which were female. ${ }^{19}$ This situation is inversely proportional to that of pulmonary TB sufferers for which there are more male sufferers. ${ }^{20}$

There is a greater level of awareness in women about health, meaning that more women have health checks and subsequently EPTB is more often found in women. ${ }^{21}$ On the other hand, in women are found lower levels of adequate protein intake and less energy .9 This can be a cause of decreased immunity, which makes women more susceptible to infectious diseases. This needs more in-depth research.

\section{Spatial and pattern distribution of EPTB in Samarinda City}

The results showed that the 46 EPTB patients were spread in 10 subdistricts in Samarinda, and mostly found in Samarinda Ulu Subdistrict (26\%), while Palaran Subdistrict and North Samarinda

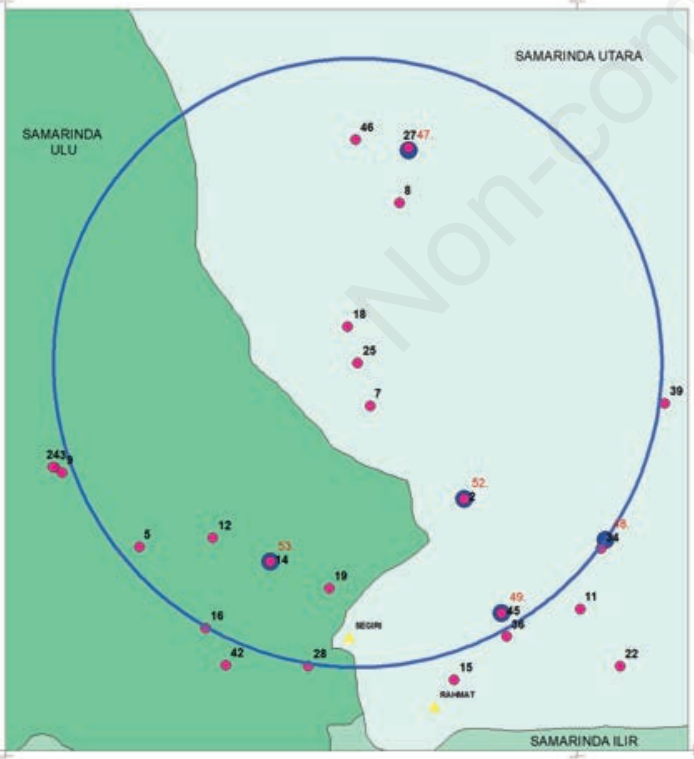

PETA KOTA SAMARINDA KALIMANTAN TIMUR
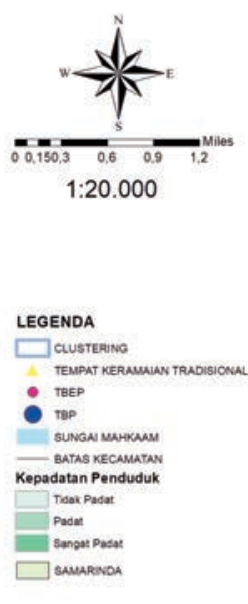

Figure 2. Distribution patterns of EPTB and pulmonary TB patients in Samarinda City. One clustering in 17 patients was obtained from EPTB and pulmonary TB analysis, which consisted of 5 pulmonary TB patients and 12 EPTB patients centered on $0.458159 \mathrm{~S} / 117.149945 \mathrm{E}$ with a radius of $3.19 \mathrm{~km}$. The formation of clustering indicated there is a geographical relationship between EPTB and pulmonary TB in Samarinda city. Based on Purely Spatial analysis with the Bernoulli model, a relative risk of 5.29 is obtained.
Subdistrict hosted only $2.2 \%$ of the cases each (Table 2). A total of 7 people have a history of suffering from pulmonary TB: 5 of the patients had a history of pulmonary TB, two patients had a history of direct contact with pulmonary TB patients in the surrounding environment. The high incidence of EPTB in Samarinda Ulu sub-district correlates with the highest TB pulmonary incidence rate in this sub-district. This area is also the most populous sub-district in Samarinda city. These results are consistent with research conducted in Maryland, USA, which stated that TB is mostly due to social factors, therefore more common in poor and densely populated areas. ${ }^{22}$

The results summarized in Table 2 showed 46 of EPTB patients were located in 10 subdistricts in Samarinda and mostly found in Samarinda Ulu Subdistrict (26\%), while in Palaran Subdistrict and North Samarinda Subdistrict only $2.2 \%$ each. The high incidence of TBEP in Samarinda Ulu sub-district correlates with the highest TB pulmonary incidence rate in this sub-district and this area is also the most populous subdistrict in Samarinda city.

SaTScan Space-Time Permutation model analysis showed 3 clustering of EPTB. Cluster 1 consisted of 9 patients centered at $-0.504177 \mathrm{~S} / 117.118058 \mathrm{E}$ with a radius of $2.91 \mathrm{~km}$. Cluster 2 consisted of 4 patients centered at $-0.476895 \mathrm{~S} /$ $117.141700 \mathrm{E}$ with a radius of $0.97 \mathrm{~km}$, while cluster 3 consisted of 2 patients centered at $-0.517031 \mathrm{~S} / 117.092132 \mathrm{E}$ with a radius of $1.13 \mathrm{~km}$ (Figure 1). These results proved that there are sources of transmission among these community groups that are in one cluster. Another factor is the tendency of people to live in groups with individuals who are all from lower socioeconomic groups, who have a greater risk of becoming infected with TB. This causes differences in the incidence of cases between geographical locations, resulting in clustering. ${ }^{23,24}$

The results also showed the cluster formed were mostly located in densely populated districts and traditionally crowded places, as this facilitates the transmission of pulmonary TB through direct contact with a fellow patient. Pulmonary TB is transmitted through droplets with a source of infection, namely people with pulmonary TB disease who cough, sneeze, or talk. Coughing from pulmonary TB patient can produce 3000 droplet nuclei and can stay in the air for a long time. Direct sunlight can quickly kill the bacteria, but they can survive in a dark and humid environments. ${ }^{25}$

One clustering of 17 patients was obtained from EPTB and pulmonary TB analysis, which consisted of 5 pulmonary 
TB patients and 12 EPTB patients centered on $-0.458159 \mathrm{~S} / 117.149945 \mathrm{E}$ with a radius of $3.19 \mathrm{~km}$ (Figure 2). The formation of clustering indicated there is a relationship between EPTB and pulmonary TB geographically in Samarinda city. The presence of pulmonary TB in the cluster area can be a potential source of transmission to the surrounding environment. Based on Purely Spatial analysis with the Bernoulli model, a relative risk of 5.29 is obtained, which means that people in the cluster have a 5.29 times greater risk of suffering from TB than those who live outside the cluster.

\section{Conclusions}

The conclusion of this study was the individuation of 3 EPTB clusters in Samarinda City in 2017 in densely populated areas. There is a geographical relationship between EPTB and pulmonary TB in the city of Samarinda with a relative risk of 5.29 times. Spatial analysis of EPTB provides information on the spread of the source of infection from patients with active pulmonary TB.

\section{References}

1. World Health Organization. Global Tuberculosis Report. Geneva: World Health Organization;2018. Available from: http://apps.who.int/medicinedocs/documents/s23553en/s23553en.pd f Accessed: August 2019.

2. Peto HM, Pratt RH, Harrington TA, LoBue PA, Armstrong LR. Epidemiology of extrapulmonary tuberculosis in the United States, 1993-2006. Clin Infect Dis 2009;49:1350-7.

3. Sandgren A, Hollo V, van der Werf MJ. Extrapulmonary tuberculosis in the European Union and European Economic Area, 2002 to 2011. Euro Surveill 2013;18:20431.

4. Krujishaar, ME, Abubakar. Increase in extrapulmonary tuberculosis in England and Wales 1999-2006. Thorax 2009;64:1090-5.

5. Arsang-Jang S, Mansourian M, Amani F, Jafari-Koshki T. Epidemiologic Trend of Smear-Positive, Smear-
Negative, Extra Pulmonary and Relapse of Tuberculosis in Iran (2001-2015); A Repeated Cross Sectional Study. J Res Health Sci 2017;17:e00380.

6. Gaur PS, Suryakant, Bhaskar R, et al. Incidence and Clinical profiles of Pulmonary and Extra-Pulmonary Tuberculosis patients in North Indian population: A hospital based Retrospective study. Int J Res Dev Pharm L Sci 2017; 6:2773-2778.

7. Gomes T, Reis-Santos B, Bertolde A, et al. Epidemiology of extrapulmonary tuberculosis in Brazil: a hierarchical model. BMC Infect Dis 2014;14:9.

8. Kementerian Kesehatan RI. Profil Kesehatan Indonesia 2015. Jakarta: Kementerian Kesehatan RI: 2016. Available from: www.depkes. go.id/.../profil-kesehatan indonesia/profil-kesehatan-Indonesi. Accessed: August 2019

9. Kementerian Kesehatan RI. Data dan Informasi Profil Kesehatan Indonesia 2018. Jakarta: Kementerian Kesehatan RI: 2019. Available from: www.depkes.go.id/.../profil-kesehatan-indonesia/Data-dan Informasi. Accessed: August 2019.

10. Davies PD, Barnes P, Gordon SB. Clinical Tuberculosis. 4th Edition London. 2008. Hodder Arnold, Hachette Livre.

11. Golden MP, Vikram HR. Extrapulmonary tuberculosis: An overview. Am Fam Physician 2005;72:1761-8.

12. Sandgren A, Hollo V, van der Werf MJ. Extrapulmonary tuberculosis in the European Union and European Economic Area, 2002 to 2011. Euro Surveill 2013;18:20431.

13. Ade S, Harries AD, Trébucq A, et al. National profile and treatment outcomes of patients with extrapulmonary tuberculosis in Bénin. PLoS One 2014;9:e95603.

14. Tiwari N, Adhikari CM, Tewari A, Kandpal V. Investigation of geo-spatial hotspots for the occurrence of tuberculosis in Almora district, India, using GIS and spatial scan statistic. Int $\mathbf{J}$ Health Geogr 2006;5:33.

15. Mesgary MS, Masoomi Z. GIS Application in Public Health as Decision Making Support System and
It's Limitation in Iran. Retrieved from World Applies Science Journal 2008;1: 73-77.

16. Ruditya DN. Hubungan antara Karakteristik Penderita TB dengan Kepatuhan Memeriksa Dahak Selama Pengobatan. Universitas Airlangga 2015;3:122-133.

17. Fatmah. Respons Imunitas yang Rendah pada Tubuh Manusia Usia Lanjut. Jurnal Universitas Indonesia 2006; 47-53.

18. Gracia-Rodriguez J, Alvarez-Diaz H, Lorenzo-Garcie M, et al. Extrapulmonary Tuberculosis: Epidemiology and Risk Factors.Enferm Infect Microbiol Clin 2011;29:502-9.

19. Marcellina, E. R.Profil Pasien Tuberculosis Ekstra Paru Di Laboratorium Patologi Anatomi RSUD AWS Samarinda tahun 2016. Samarinda: Program Studi Pendidikan Dokter Fakultas Kedokteran Universitas Mulawarman 2016.

20. McNabb SJ, Chungong S, Ryan M, et al. Conceptual Framework of Public Health Survellance and Action and Its Application in Health Sector Reform. BMC Public Health 2002;2:2.

21. Bayat S, Gol-Mohamadi A, Sarbazi MR, et al. A Seven Year Retrospective Study on Epidemiology and Clinical Characteristics of Tuberculosis in Iran. Arch Clin Infect Dis 2013;8, 1-5.

22. Prussing C, Castillo-Salgado C, Baruch N, Cronin W. GeoEpidemiologic and Molecular Characterization to Identify Social, Cultural, and Economic Factors Where Targeted Tuberculosis Control Activities Can Reduce Incidence in Maryland, 2004-2010. Public Health Rep 2013; 128:104-14

23. Nunes C. Tuberculosis Incidence in Portugal: Spatiotemporal Clustering. Int J Health Geogr 2007; 6:30

24. Onozuka D, Hagihara A. Geographic Prediction of Tuberculosis Clusters in Fukuoka, Japan, Using The Space Time Scan Statistic. BMC Infect Dis 2007; 7:26.

25. Musadad A. Hubungan Faktor Lingkungan Rumah Dengan Penularan TB Paru Kontak Serumah. JEK 2006; 5:486-496. 